\title{
Profile of pediatric eye trauma at Hospital de Base do Distrito Federal (HBDF), Brasília, Brazil
}

\author{
Juliana Tessari Dias Rohr ${ }^{1 *}$, Procópio Miguel dos Santos ${ }^{2}$, Regina Candido Ribeiro dos Santos ${ }^{2}$, Camila Viana Vieira ${ }^{3}$, \\ Lylian Moura Fé ${ }^{3}$, Rodrigo Luis Solano ${ }^{3}$, Túlio Frade Reis ${ }^{3}$, Marcell de Oliveira Leão ${ }^{3}$, Viníclus da Costa Guimarães ${ }^{3}$ \\ ${ }^{1} \mathrm{MSc}$ in Health Sciences from Universidade de Brasilia (UnB) - Ophthalmologist of the government of the Federal District, Brasilia, DF, Brazil \\ ${ }^{2}$ PhD in Medicine (Ophthalmology) from Universidade Federal de São Paulo (Unifesp) - Lecturer of the Faculdade de Medicina do Governo do Distrito Federal. Supervisor of the Graduate Program, Faculdade de Ciências \\ da Saúde, UnB, Brasília, DF, Brazil \\ ${ }^{3} \mathrm{MD}$ - Resident in Ophthalmology, Hospital de Base do Distrito Federal, Brasília, DF, Brazil
}

Study conducted at Hospital de Base do Distrito Federal (HBDF), Brasília, DF, Brazil

Article received: $11 / 5 / 2014$ Accepted for publication: 2/19/2015

*Correspondence: Address: SMHS - Área Especial - Q. 101 Brasília, DF - Brazil Postal code: $70330-150$ Phone: +55 61 3315-1200 julianarohr@yahoo.com.br

http://dx.doi.org/10.1590/1806-9282.62.04.324

\section{SUMmARY}

Objective: To describe the epidemiological profile of ocular trauma in children at the HBDF emergency department.

Method: Descriptive, cross-sectional study. We evaluated 103 cases of ocular trauma in children less than 15 years between July 2012 and January 2013. The factors evaluated through semi-structured questionnaire available online were: age, gender, adult supervision, mechanism, type of trauma, time and place, site and nature of injury, visual acuity, need for hospitalization and/or surgery, type of surgery, mother's level of education, and family income.

Results: The average age of patients studied was 7.5 years. Boys (68\%) predominate in all age groups. Blunt trauma prevailed (55.3\%), followed by open (20\%). Most of the cases occurred at home, 14 to 20 hours before seeking hospital care. The most common causes were: wood, stone, bicycle, broken glass, and falls. The cornea was affected in $54 \%$. Visual acuity was $\geq 20 / 40$ in $68.9 \%$. Primary repair of the eye wall was indicated in $70.37 \%$ ( $\mathrm{p}$-value $=0.022$ ). Open traumas were more severe $(p$-value $=0.005)$ and had more need for intervention $(p$-value $=0.000)$. The injuries occurred despite the presence of adult supervision in $54 \%$ ( $\mathrm{p}$-value $=0.002$ ). The most severe injuries predominated in the age range $7-15$ years $(\mathrm{p}=0.001)$.

Conclusion: Ocular trauma was more frequent among boys. The mechanisms of injury are the most diverse, and prevail at home. Blunt trauma prevails, but the visual impact is due to open trauma. Programs of prevention and education on child ocular trauma are needed.

Keywords: risk factors, hospital emergency service, eye injury, child, epidemiology.

\section{INTRODUCTION}

Sight is essential for full child development, influencing learning, language for expression and reception, and the ability to interact. ${ }^{1}$

It is estimated that 20 to $50 \%$ of eye traumas occur in children, ${ }^{2,3}$ constituting a serious public health problem, ${ }^{3}$ which can result in blindness in addition to long-term functional repercussions. ${ }^{3}$

Motor disability, a tendency to imitate adult behavior, relative ignorance regarding risks, and natural curiosity, as well as cultural issues, contribute to children being more susceptible. ${ }^{4}$
Despite clinical management being similar to that of cases in adults, child trauma has its own particularities, such as the etiology, surgical recovery and the major socioeconomic impact due to the long life expectancy of children. $^{2}$

In addition, the prognosis of these injuries in children is worse, because there is a greater tendency to ocular atrophy in puncture wounds and a serious problem of amblyopia, which is understood as the failure in the consolidation of visual acuity, resulting from lack of stimuli or inappropriate stimuli during the critical period of development, when the brain is labile to adjust 
to changes in visual experience, which occurs up to the eighth year of life. ${ }^{1}$

Currently the majority of studies are conducted in developed countries; ${ }^{3}$ however, local epidemiology is essential for the development of preventive strategies. ${ }^{6}$

The aim of this study is to describe the epidemiological profile of emergency pediatric eye trauma at the Hospital de Base do Distrito Federal (HBDF), Brazil, a trauma reference center for the greater federal district area, contributing to the planning and implementation of preventive measures for this injury.

\section{Method}

A cross-sectional, descriptive study was carried out, based on the evaluation of cases of incidents of acute eye trauma among children from 0 to 15 years admitted to the ophthalmology emergency service at the HBDF, Brasília, Distrito Federal (DF), from July 2012 to January 2013.

The HBDF is a teaching hospital, and is included in the hierarchical health care network, with the mission of providing high complexity care. It is considered a trauma reference center for the greater Brasília area, as well as receiving cases from neighboring states.

The survey included all cases of acute eye trauma, of whatever nature, in children under 15 years of age, with no cases of abstention. The exclusion criteria were: age of over 15 years, admissions for chronic sequelae from eye trauma or cases due to other acute or chronic degenerative causes, for example: conjunctivitis, hordeolum, keratoconus, pterygium, and more.

The data were collected from a semi-structured questionnaire developed for the purpose of research, based on the literature review, and made available in an online platform (Google Drive) for completion in real time. We assessed the age (in full years), sex, presence of adult supervision at the time of the trauma, mechanism and type of trauma, time and place of the trauma, site and nature of the injury, visual acuity without correction, the need for hospitalization and/or surgery, type of surgery, household income and the mother's level of education.

To evaluate the type of trauma the classification of the Birmingham Eye Trauma Terminology (BETT) was used, which is recommended by the International Society of Ocular Trauma, and classifies trauma of mechanical nature. ${ }^{7}$ The BETT defines eye bulb as a whole as a reference element; thus it proposes that the trauma with involvement of the entire thickness of the wall (cornea/ sclera), with or without involvement of the retina and choroid, is classified as an open trauma. Closed or blunt trauma, on the other hand, would be classified as one in which the eye wall remains intact. ${ }^{7}$ Trauma with eyelid involvement, chemical trauma and burns were added to this classification. ${ }^{4}$

The eye exam of the child assessed the parameters of: visual acuity (without correction), external inspection with or without the aid of a flashlight, pupillary light reflex, ocular motility, biomicroscopy with slit lamp and ophthalmoscopy, whenever possible, in accordance with the age of the child and respecting the limitations arising from the moment of stress caused by the trauma.

The evaluation of visual acuity was standardized, with the fixation and following test held in pre-schoolers (0-6 years), and visual acuity measured by the Snellen chart in schoolchildren ( $7-15$ years).

The statistical analyses were performed using SPSS 18.0 software. Bivariate analysis, chi-square test, Student's t-test and Fisher's exact test were used, considering statistical significance p-value $<0.05$.

The research was approved and conducted with the consent of the Research Ethics Committee CEP/FS at Universidade de Brasília under registration number $138 / 12$, and met the requirements of the Declaration of Helsinki, including obtaining informed consent in writing (from the legal guardians of the participants of the study), ensuring the right to non-participation and confidentiality of the information obtained.

\section{Results}

Of the 103 cases evaluated, $68 \%$, were male and $32 \%$ were female; with a ratio of 2.12 boys for every girl and an average age of 7.5 years.

Most of the cases sought hospital care on the same day as the accident $(43.7 \%)$.

The accidents occurred mainly between 2 pm and 8 pm (51\%), at home (62.1\%) and with adult supervision (54\%), being caused by the child itself in $54.4 \%$ of cases. In one case shaken baby syndrome was suspected, and the patient was promptly forwarded to be followed up by the Social Service sector of the hospital.

The causative agents varied, with the most common being: wood (11.7\%), stone (8.7\%), falls (5.8\%), cycling (3.9\%) and pieces of glass (3.9\%). The less common agents included: cement, nails, fingernails and clothesline with $2.9 \%$ each; wire, being run over, balls, physical contact, knives, irons, pencils, mobile phones, with $1.9 \%$ each; and other agents such as stairs, soap, party explosives, glue, dog bite, ammonia, plastic, alcohol, among others, with $1 \%$ of cases.

The most prevalent sites of ocular injury were the conjunctiva (54\%), cornea (54\%) and eyelid (53\%), while 
lens $(11 \%)$, scleral $(5 \%)$ and posterior pole injuries (1\%) were rare.

To analyze the involvement of each eye structure separately, it was observed that in purely corneal injuries there was a prominence of keratitis and corneal laceration (12 cases each, 16.43\%), and corneal abrasion (10 cases, $13.69 \%)$.

In eyelid injuries edema and excoriation (14 cases, $19.17 \%$ ) were the most common, followed by eyelid laceration ( 13 cases, $17.80 \%$ ), bruising ( 3 cases, $4.10 \%$ ), burns ( 2 cases, $2.73 \%$ ) and one case of eyelid ptosis (1.36\%).

The majority of injuries to the conjunctiva were cases of hyposphagma (13 cases, $17.80 \%$ ), followed by hyperemia (4 cases, $5.47 \%$ ) and laceration ( 3 cases, $4.10 \%$ ). There were three cases of scleral laceration (4.10\%) and one case (1.36\%) of isolated involvement of the lens (phacodonesis).

To evaluate joint injuries of multiple ocular structures a wide range of abnormalities were found, such as: 14 cases of corneal laceration associated with the traumatic cataract and/or iridian impairment or otherwise (46.7\%), and one case of extensive corneal-scleral laceration (3.4\%), in addition to an association between eyelid and corneal injuries (laceration and/or eyelid edema with keratitis) in six cases $(20 \%)$, and also five cases $(16.7 \%)$ of injury to the conjunctiva and cornea (keratitis with hyposphagma).

There were three cases (10\%) of intraocular foreign body associated with corneal laceration ( 2 caused by wood and 1 by glass) and one case (3.4\%) of severe trauma with the association of eyelid laceration, corneal laceration, cataract, iridodialysis, vitreous hemorrhage, and retinal detachment.

There was no significant difference in relation to laterality (45.6\% right eye and $47.6 \%$ left eye), and $6.8 \%$ showed bilateral injury.

Closed trauma predominated (55.3\%), followed by open $(20 \%)$, eyelid (18.4\%) and chemical trauma (3.9\%) and burns (2.9\%) (Table 1$)$.

The largest number of closed traumas $(42.10 \%)$ occurred between 2 to 6 years of age. In relation to open trauma, $55 \%$ occurred between 11 to 15 years, although there is no significant association between the variables (Table 2).

The most serious traumas predominated between 7 and 15 years of age $(24 \%)$ ( $\mathrm{p}$-value $=0.001)$ (Table 1$)$.

Most cases (68.9\%) showed good visual acuity after the trauma. However, 21 (20.4\%) patients suffered severe loss (Table 1).

When correlating visual acuity with the classification of the trauma (BEET), open traumas proved to be more severe $(p$-value $=0.000)$ (Table 1$)$.
TABLE 1 Factors related to severity of trauma $(n=100)$

$\begin{array}{lll}\text { Severity of trauma }(n=\%) & \text { Chi-squared } \\ \text { Mild } & \begin{array}{l}\text { Moderate/ } \\ \text { Severe }\end{array} & \left(\chi^{2}\right) \\ & \end{array}$

\begin{tabular}{llll}
\hline \multicolumn{1}{l}{ Age } \\
\hline 0 to 6 years & $37(37)$ & $5(5)$ & $\mathrm{p}=0.001$ \\
\hline 7 to 15 years & $37(34)$ & $24(24)$ & \\
\hline \multicolumn{4}{l}{ Classification of trauma } \\
\hline Closed & $41(41)$ & $14(14)$ & \\
\hline Open & $6(6)$ & $14(14)$ & \\
\hline Eyelid & $19(19)$ & $0(0)$ & $\mathrm{p}=0.000$ \\
\hline Burn & $2(2)$ & $0(0)$ & \\
\hline Chemical & $3(3)$ & $1(1)$ & \\
\hline
\end{tabular}

\begin{tabular}{llll}
\hline \multicolumn{3}{l}{ Surgical indication } & \\
\hline Yes & $12(12)$ & $15(15)$ & $\mathrm{p}=0.000$ \\
\hline No & $59(59)$ & $14(14)$ & \\
\hline
\end{tabular}

\begin{tabular}{|c|c|c|c|}
\hline \multicolumn{4}{|l|}{ Type of surgery } \\
\hline $\begin{array}{l}\text { Primary closure of } \\
\text { the eye wall }\end{array}$ & $6(6)$ & $13(13)$ & $p=0.022$ \\
\hline $\begin{array}{l}\text { Suture/Eyelid } \\
\text { reconstruction }\end{array}$ & $5(5)$ & $0(0)$ & \\
\hline Other & $1(1)$ & $2(2)$ & \\
\hline \multicolumn{4}{|c|}{ Mother's level of education } \\
\hline Primary school & $29(29)$ & $17(17)$ & $\mathrm{p}=0.278$ \\
\hline High school & $30(30)$ & $8(8)$ & \\
\hline University & $8(8)$ & $4(4)$ & \\
\hline \multicolumn{4}{|l|}{ Income } \\
\hline Up to $2 \mathrm{MW}$ & $38(38)$ & $20(20)$ & $p=0.270$ \\
\hline More than $2 \mathrm{MW}$ & $26(26)$ & $8(8)$ & \\
\hline
\end{tabular}

Mild trauma: visual acuity $\geq 20 / 40$ and fixed, capable to detect and follow light and objects; moderate/severe trauma: visual acuity worst than 20/50 up to no perception of light; MW: minimum wages.

Hospitalization occurred in $28.2 \%$, while in $26.2 \%$ there was surgical intervention ( $\mathrm{p}$-value $=0.000)$ (Table 3$)$. The severity of the injury correlated with the type of surgery ( $\mathrm{p}$-value $=0.022$ ), the most common being primary closure of the eye wall (Table 1).

When analyzing the classification of the trauma, visual acuity and the need for surgery, it was noted that open trauma ( $\mathrm{p}$-value $=0.000$ ) (Table 3 ), as well as patients with worst visual acuity upon admission ( $\mathrm{p}$-value $=0.000$ ) (Table 1) were those most in need of intervention.

In relation to socioeconomic characteristics, most mothers completed primary education (39.8\%) and family income was up two minimum wages (58\%), with income $(p$-value $=0.270)$ and level of education ( $p$-val$\mathrm{ue}=0.278$ ) having no influence on the severity of the injury. However, severe traumas were more frequent in 
TABLE 2 Variables correlated to age range $(n=103)$.

\begin{tabular}{|c|c|c|c|c|c|c|c|}
\hline Age range (\%) & & Less than 2 y.o. & 2 to 6 y.o. & 7 to 10 y.o. & 11 to 15 y.o. & Total & \\
\hline \multirow{6}{*}{$\begin{array}{l}\text { Classification of } \\
\text { trauma }\end{array}$} & Open & $1(0.9)$ & $3(2.9)$ & $5(4.8)$ & $11(10.6)$ & $20(19.4)$ & \multirow[t]{6}{*}{$\mathrm{p}=0.253^{*}$} \\
\hline & Closed & $4(3.8)$ & $24(23.3)$ & $12(11.6)$ & $17(16.5)$ & $57(55.3)$ & \\
\hline & Eyelid & $1(0.9)$ & $9(8.7)$ & $6(5.8)$ & $3(2.9)$ & $19(18.4)$ & \\
\hline & Burn & $1(0.9)$ & $1(0.9)$ & $0(0)$ & $1(0.9)$ & $3(2.9)$ & \\
\hline & Chemical & $0(0)$ & $1(0.9)$ & $2(1.9)$ & $1(0.9)$ & $4(3.8)$ & \\
\hline & Total & $7(6.8)$ & $38(36.9)$ & $25(24.2)$ & $33(32.0)$ & $103(100)$ & \\
\hline \multirow{3}{*}{$\begin{array}{l}\text { Supervision at the } \\
\text { moment of trauma }\end{array}$} & Yes & $6(5.8)$ & $27(26.2)$ & $7(6.7)$ & $16(15.5)$ & $56(54.4)$ & \multirow{3}{*}{$\begin{array}{l}\mathrm{p}=0.002^{*} \\
\mathrm{p}=0.004^{* *}\end{array}$} \\
\hline & No & $1(0.9)$ & $11(10.6)$ & $18(17.4)$ & $17(13)$ & $47(45.6)$ & \\
\hline & Total & $7(6.7)$ & $38(36.8)$ & $25(24.1)$ & $33(28.5)$ & $103(100)$ & \\
\hline
\end{tabular}

${ }^{*} \chi 2$ : Chi-squared. ${ }^{*}$ Student's t test, considering standard deviation and error.

children whose mother's level of education was primary education (17.7\%), and with household income of up to two minimum wages $(21.7 \%)$ (Table 1$)$.

There is an association between age and presence or absence of supervision $(\mathrm{p}=0.002)$. Children under six years old had a higher probability of being supervised and suffered fewer accidents compared to those over the age of seven years (Table 2).

TABLE 3 Relation among surgical indication, trauma classification and need for hospital admission $(n=103)$.

\begin{tabular}{|c|c|c|c|}
\hline & \multicolumn{3}{|c|}{ Surgical indication (\%) } \\
\hline & Yes & No & \\
\hline \multicolumn{4}{|c|}{ Admission } \\
\hline Yes & $26(25.2)$ & $3(2.9)$ & $\mathrm{p}=0.000 *$ \\
\hline No & $1(1.0)$ & $73(70.9)$ & \\
\hline \multicolumn{4}{|c|}{ Classification of trauma } \\
\hline Closed & $4(3.9)$ & $53(51.5)$ & \\
\hline Open & $19(18.4)$ & $1(1.0)$ & $\mathrm{p}=0.000^{* *}$ \\
\hline Eyelid & $4(3.9)$ & $15(14.6)$ & \\
\hline Burn & $0(0.0)$ & $3(2.9)$ & \\
\hline Chemical & $0(0.0)$ & $4(3.9)$ & \\
\hline
\end{tabular}

* Fisher's exact test; ${ }^{* *} \chi 2$ : Chi-squared.

\section{Discussion}

This was the first work in the Emergency Department of the HBDF with the intention of describing the epidemiology of pediatric eye trauma.

We decided to carry out an exploratory study with the goal of providing first contact for investigation, because the knowledge and understanding about the phenomenon under study were insufficient or non-existent.

Despite all the physical limitations and the large volume of treatments at the ophthalmic emergency service, special time was dedicated to these patients because they were cases of eye trauma in the pediatric population, a fact which, by itself, mobilizes the entire medical team on duty.

At times it was not possible to perform the complete examination due to stressful circumstances associated with the trauma, rendering the child uncooperative, and making it impossible to assess visual acuity in three cases and perform the ophthalmoscopy in nine cases. These cases, and all others that required return and monitoring were later assessed routinely in the ophthalmic emergency department, depending on the severity of the injuries.

It was observed that boys were most affected, perhaps for engaging in activities of higher risk compared to girls. ${ }^{8-13}$ For this reason, gender is considered to be a strong risk factor. ${ }^{2,4-6,8,14-16}$ The male:female ratio varies according to the population and age group, reaching 5.2:1. ${ }^{13}$ However, in most studies ${ }^{2,4-6,8,14-16}$ the ratio is between 2 to $3: 1$, which corroborates with this study.

Children between 2 and 6 years were most susceptible, a similar finding to other studies, ${ }^{2,4,12,17}$ probably due to immaturity of the motor system, limited sense of risk assessment and the natural curiosity of childhood. ${ }^{4}$

The lack of standardization in the definition of childhood and categorization of age groups hinders a comparative analysis between studies. ${ }^{3}$

The injuries with greater visual impairment mostly affect children over 6 years; however, when seeking to define the age group at greatest risk there is divergence between studies, ${ }^{18,19}$ which reinforces the need for regional epidemiological research. ${ }^{3}$

The group of special interest from the point of view of prevention are children under the age of 8 years at risk of amblyopia, an injury that should be treated and monitored regardless of the involvement of the trauma itself, as it may cause persistent and irreversible visual loss, which 
has a great impact when it comes to children who still have a long life expectancy. ${ }^{1}$

The present study confirmed that accidents occur

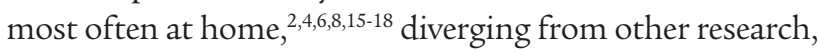
where $67.3 \%$ occurred on the street. ${ }^{17}$

In relation to time, most injuries occurred between $2 \mathrm{pm}$ and $8 \mathrm{pm}(51 \%)$, which corroborates with the literature., ${ }^{2,15,16}$

A Nigerian study ${ }^{21}$ indicated that $24.9 \%$ of accidents were caused by an adult. In a study published in Thailand, ${ }^{6}$ the patient was responsible in $18.6 \%$ of cases, followed by classmates (16\%) and siblings (6.7\%), similar to this research.

The number of cases without supervision outweighs the those supervised. ${ }^{4,16,17}$ However, our research and other studies indicate a larger number of cases where there is a responsible adult ${ }^{16,20,21}$ and a possible low quality of supervision in relation to the hazardous circumstances. ${ }^{16}$ Thus, the difficulty of those responsible to perceive hazardous circumstances in the day to day environment and removing the child from danger should be considered.

Demographic characteristics have an influence on the multifactorial mechanism of trauma. ${ }^{10,11,17,22}$ Sports activities such as badminton, squash, tennis and darts, ${ }^{23}$ as well as injuries from fireworks ${ }^{5,23}$ or circumstances of war $^{5}$ are rare in Brazil. ${ }^{4,18}$

In the present study there were no cases arising from traffic accidents, which can be explained by the positive action of Brazilian legislation. ${ }^{24}$

In relation to the involvement of eye structures, the literature corroborates with this research, with the cornea being the most affected site. , $^{2,5,6,12,17}$

In relation to laterality, there was no significant predominance of one eye over the other, and bilateral involvement is rare..$^{2,12,14,19}$

Closed trauma predominated in general; $4,11,14,16,18,19$ however some studies disagree, with a predominance of open trauma, ${ }^{2,12,17}$ which is most prevalent among those older than 7 years, ${ }^{4,16,21}$ while chemical trauma and burns were rare. ${ }^{4,16,21}$

The presence of open trauma and visual acuity are prognostic factors for eye trauma. ${ }^{21}$ Most cases presented visual acuity greater than or equal to $20 / 40 .^{4,18,25}$ However, studies have reported a higher prevalence of visual acuity between light perception and 20/100,,$^{26,27}$ which may be related to the reported prevalence of cases of open trauma. ${ }^{4,28}$

Open trauma required more specialist intervention, and primary suturing of the eye wall was the procedure conducted the most. ${ }^{4,6,26}$

Family income and mother's level of education do not relate to a worse visual prognosis, unlike the literature. ${ }^{17,29}$
In relation to level of education, there was a concentration of cases in two categories in the sample, as most of the respondents did not complete primary education, but also a large part completed high school or had incomplete higher education, which demonstrates an evolution to the average level of education in Brazil cited in a previous study. ${ }^{29}$

In relation to family income, only two categories were used, as most patients were included in a wage bracket of up to 2 minimum wages, which may be related to the fact that the study was aimed at a population served in the public sector, and the study did not include child trauma care at private hospitals, with other studies needed to clarify the impact of socioeconomic aspects of child eye trauma.

\section{Conclusion}

Trauma in childhood is a public health problem. In this study it was observed that the male gender was the most affected. There are multiple trauma mechanisms, and injuries at home predominate, despite supervision. Closed trauma is most common in all ages, but the greatest impact on sight is caused by open trauma. Severe trauma is more frequent in those aged over 7 years. Level of education and family income did not influence the severity of the injury.

Therefore, it is clear that eye trauma has a major impact on visual acuity in the population studied, with the promotion and prevention of eye health being essential tools to address that.

Awakening knowledge about the risks especially in the educational, sports and home spheres during childhood and adolescence through practicing safer activities under the supervision of parents or responsible adults is the best way of preventing eye trauma.

Accordingly, educational campaigns in public health are needed, as well as recognition and prevention of potentially damaging factors and health education strategies covering both the home environment and the streets, for example: control of the toy industry, rules on the use of personal protective equipment at work and in certain sports (glasses, helmets), compulsory use of seat belts in vehicles, legislation on fireworks, etc. ${ }^{26}$

These measures are only possible from the moment in which the profile of the problem is established, which helps to understand the difficulties to be faced and, from this point, to endorse protection, promotion and prevention actions aimed at better visual health of children and adolescents. 


\section{Resumo}

Perfil do trauma ocular pediátrico no Hospital de Base do Distrito Federal (HBDF), Brasília, Brasil

Objetivo: descrever o perfil epidemiológico do trauma ocular infantil na urgência do HBDF.

Método: estudo transversal, descritivo. Avaliaram-se 103 casos de trauma ocular em menores de 15 anos entre julho de 2012 e janeiro de 2013, por meio de aplicação de questionário semiestruturado disponível online: idade, sexo, presença de supervisão, mecanismo, tipo do trauma, local e hora, sítio e natureza da injúria, acuidade visual, necessidade de internação e/ou cirurgia, tipo de cirurgia, escolaridade materna e renda familiar.

Resultados: a média de idade dos pacientes analisados foi 7,5 anos. Os meninos (68\%) predominaram em todas as faixas etárias. O trauma fechado prevaleceu (55,3\%), seguido do aberto (20\%). A maioria dos casos ocorreram em casa, no período de 14 às 20 horas. As causas mais comuns foram: madeira, pedra, bicicleta, caco de vidro e quedas. A córnea foi acometida em 54\%. A acuidade visual foi $\geq 20 / 40$ em $68,9 \%$. Indicou-se sutura primária da parede em $70,37 \%$ $(\mathrm{p}$-valor $=0,022)$. O trauma mais grave $(\mathrm{p}$-valor $=0,005)$ e que mais necessitou de intervenção ( $\mathrm{p}$-valor $=0,000$ ) foi o aberto. As injúrias ocorreram, apesar da presença de supervisão de um adulto, em 54\% ( $\mathrm{p}$-valor=0,002). Os traumas mais graves predominaram entre $7-15$ anos ( $\mathrm{p}$-valor $=0,001$ ). Conclusão: o trauma ocular infantil foi mais frequente nos meninos. Os mecanismos de lesão são os mais diversos e predominaram no domicílio. O trauma fechado prevaleceu; porém, o maior impacto visual decorreu do trauma aberto. São necessários programas de prevenção e educação em trauma ocular infantil.

Palavras-chave: fatores de risco, serviço hospitalar de emergência, lesões oculares, criança, epidemiologia.

\section{References}

1. Nakanami C, Vasconcelos G. Abordagem clínica da criança com baixa visão. In: Série Oftalmologia Brasileira Óptica. Refração e visão subnormal. Rio de Janeiro: Cultura Médica, 2008. p.457-68.

2. Thompson CG, Kumar N, Billson FA, Martin F. The aetiology of perforating ocular injuries in children. Br J Ophthalmol. 2002; 86(8):920-2.
3. Négrel AD, Thylefors B. The global impact of eye injuries. Ophthalmic Epidemiol. 1998; 5(3):143-69.

4. Serrano JC, Chalela P, Arias JD. Epidemiology of childhood ocular trauma in a northeastern Colombian region. Arch Ophthalmol. 2003; 121(10):1439-45.

5. Hosseini H, Masoumpour M, Fatemeh KF, Razeghinejad M, Salouti R, Nowroozzadeh M. Clinical and epidemiologic characteristics of severe childhood ocular injuries in Southern Iran. Middle East Afr J Ophthalmol. 2011; 8(2):136-40.

6. Liu M, Chang Y, Tseng S, Cheng H, Huang F, Shih M. Major pediatric ocular trauma in Taiwan. J Pediatr Ophthalmol Strabismus. 2010; 47(2):88-95.

7. Kuhn F, Morris R, Witherspoon CD, Mester V. The Birmingham Eye Trauma Terminology system (BETT). J Fr Ophtalmol. 2004; 27(2):206-10.

8. Armstrong GW, Kim JG, Linakis JG, Mello MJ, Greenberg PB. Pediatric eye injuries presenting to United States emergency departments: 2001-2007. Graefes Arch ClinExp Ophthalmol. 2013; 251(3):629-36.

9. Mowatt L, McDonald, Ferron BD. Paediatric ocular trauma admissions to the University Hospital of the West Indies 2000-2005. West Indian Med J. 2012; 61(6):598-604

10. Cascairo MA, Mazow ML, Prager TC. Pediatric ocular trauma: a retrospective survey. J Pediatr Ophthalmol Strabismus. 1994; 31(5):312-7.

11. Labrada Rodrigues YH, Flores Pérez D, González Hess L. Trauma ocular en niños. Rev Cub Oftalmol. 2003; 16(2):3.

12. Rostomian K, Thach AB, Isfahani A, Pakkar A, Pakkar R, Borchert M. Open globe injuries in children. J AAPOS. 1998; 2(4):234-8.

13. Mensah A, Fany A, Adjorlolo C, Touré ML, Kasieu M, Mihluedo KA, et al. Épidémiologie des traumatismes oculaires de l'enfant à Abidjan. SANTE. 2004; 14(4):239-43

14. Lee CH, Su WY, Lee L, Yang ML. Pediatric ocular trauma in Taiwan. Chang Gung Med J. 2008; 31(1):59-65.

15. Sharifzadeh M, Rahmanikhah E, Nakhaee N. Pattern of pediatric eye injuries in Tehran, Iran. Int Ophthalmol. 2013; 33(3):255-9.

16. Diniz CM, Tzelikis PFM, Alvim HS, Gonçalves RM, Rodrigues Jr A, Trindade FC. Trauma ocular em crianças abaixo de 15 anos: prevenção baseada em estatísticas. Rev Bras Oftalmol. 2003; 62(2):96-101.

17. El-Sebaity DM, Soliman W, Soliman AM, Fathalla AM. Pediatric eye injuries in upper Egypt. Clin Ophthalmol. 2011; 5:1417-23.

18. Cariello AJ, Moraes NSB, Mitne S, Oita CS, Fontes BM, Melo Jr LAS Epidemiological findings of ocular trauma in childhood. Arq Bras Oftalmol. 2007; 70(2):271-5.

19. MacEwen CJ, Baines PS, Desai P. Eye injuries in children: the current picture. Br J Ophthalmol. 1999; 83(8):933-6

20. Salvin JH. Systematic approach to pediatric ocular trauma. Curr Opin Ophthalmol. 2007; 18(5):366-72.

21. Ashaye AO. Eye injuries in children and adolescent: a report of 205 cases. J Natl Med Assoc. 2009; 101(1):51-6.

22. Garcia TA, McGetrick BA, Janik JS. Ocular Injuries in children after major trauma. J Pediatr Ophthalmol Strabismus. 2005; 42(6):349-54.

23. Abbott J, Shah P. The epidemiology and etiology of pediatric ocular trauma. Surv Ophthalmol. 2013; 58(5):476-85.

24. Brasil. Presidência da República, Casa Civil, Subchefia para Assuntos Jurídicos (BR). Código de Trânsito Brasileiro. Lei n. 9.503, 23 de setembro de 1997.

25. Uysal Y, Mutlu FM, Sobaci G. Ocular trauma score in childhood open-globe injuries. J Trauma. 2008; 65(6):1284-6.

26. Cao H, Li L, Zhang M, Li H. Epidemiology of pediatric ocular trauma in the Chaoshan Region, China, 2001-2010. PloS One. 2013; 8(4):e60844.

27. Aghadoost D, Fazel MR, Aghadoost HR. Pediatric ocular trauma in Kashan. Arch Trauma Res. 2012; 1(1):35-7.

28. Nelson LB. Ocular injuries in childhood: an ongoing trauma. J Pediatr Ophthalmol Strabismus 2002;39(1):3

29. Moreira Jr CA, Debert-Ribeiro M, Belfort Jr R. Estudo epidemiológico das lesões oculares em crianças brasileiras. Arch Ophthalmol. 1988; 106(6):781-4. 